\title{
DAMPAK PANDEMI COVID-19 TERHADAP ANGKA PERCERAIAN
}

\author{
${ }^{1}$ Salsabila Rizky Ramadhani, ${ }^{2}$ Nunung Nurwati \\ ${ }^{1}$ salsabila19005@mail.unpad.ac.id, ${ }^{2}$ nngnurwati@yahoo.co.id \\ ${ }^{1}$ Program Studi Sarjana Ilmu Kesejahteraan Sosial FISIP Universitas Padjajaran \\ ${ }^{2}$ Pusat Studi CSR, Kewirausahaan Sosial dan Pemberdayaan Masyarakat, Universitas Padjadjaran
}

\begin{abstract}
ABSTRAK
Pandemi COVID-19 atau severe acute respiratory syndrome coronavirus 2 (SARS-CoV-2) merupakan sebuah permasalahan global yang tidak hanya berdampak pada sektor kesehatan, namun berdampak pula pada sektor perekonomian dan berdampak pada permasalahan kependudukan, salah satunya peningkatan kasus perceraian akibat dari pandemi covid-19. Selama pandemi covid 19, Indonesia mengalami peningkatan kasus perceraian sebesar 5 persen. Tulisan ini merupakan kajian literatur yang bertujuan untuk menganalisis perceraian yang terjadi di masa pandemi COVID-19 dan menghubungkannya dengan teori fungsional struktural. Penulisan artikel ini menggunakan pendekatan studi literatur. Secara umum, faktor penyebab perceraian di masa pandemi ini karena terjadi konflik dan perselisihan dalam rumah tangga yang disebabkan oleh pertengkaran/perselisihan dan permasalahan ekonomi karena banyak pekerja yang di PHK secara mendadak, sehingga keuangan keluarga menjadi tidak stabil. Mayoritas istri mengungkapkan bahwa alasan utama yang melatar belakangi terjadinya perceraian yaitu faktor ekonomi dikarenakan Suami tidak mampu untuk memenuhi seluruh kebutuhan dasar keluarga dikarenakan jumlah pendapatan yang kurang muncukupi. Oleh karena itu, sangat dibutuhkan interaksi dan komunikasi yang baik di tengah persoalan atau konflik yang menimpa pasangan suami istri untuk mencegah terjadinya perceraian serta suami istri harus dalam satu frekuensi saat menyelesaikan masalah supaya tercipta keharmonisan dalam keluarga.
\end{abstract}

Kata kunci : COVID-19, perceraian, keluarga

\begin{abstract}
The COVID-19 pandemic or severe acute respiratory syndrome coronavirus 2 (SARS-CoV-2) is a global problem that not only affects the health sector, but also affects the economic sector and has an impact on demographic problems, one of which is an increase in divorce cases as a result of the pandemic. covid-19. During the Covid 19 pandemic, Indonesia experienced an increase in divorce cases by 5 percent. This paper is a literature review that aims to analyze divorce that occurred during the COVID-19 pandemic and relate it to structural functional theory. Writing this article using a literature study approach. In general, the causes of divorce during this pandemic are due to conflicts and disputes in the household which are caused by quarrels / disputes and economic problems because many workers are dismissed suddenly, so that family finances are unstable. The majority of wives reveal that the main reason behind the occurrence of divorce is economic factors because the husband is unable to meet all the basic needs of the family due to the insufficient amount of income. Therefore, good interaction and communication is needed in the midst of problems or conflicts that befall a married couple to prevent divorce and husband and wife must be in one frequency when solving problems in order to create harmony in the family.
\end{abstract}

Keywords: COVID-19, divorce, family 
Jurnal Pengabdian dan

Penelitian Kepada Masyarakat (JPPM) e ISSN: 2775 - 1929

p ISSN: 2775 - 1910
Vol. 2 No. 1

\section{PENDAHULUAN}

Menurut World Health Organization (WHO), Corona viruses (Cov) merupakan salah satu virus yang menginfeksi sistem pernapasan. Infeksi virus ini disebut juga sebagai COVID 19. Ren, L. et al. (2020) menyatakan bahwa virus Corona dapat menyebabkan penderitanya mengalami gejala flu biasa sampai penyakit yang lebih parah seperti Sindrom Pernafasan Timur Tengah (MERS-CoV) dan Sindrom Pernafasan Akut Parah (SARS-CoV) yang dapat menyebar melalui tetesan pernapasan dari batuk maupun bersin. Berdasarkan Kementerian Kesehatan Indonesia, perkembangan kasus COVID-19 pertama kali muncul di kota Wuhan pada tanggal 30 Desember 2019 dimana Wuhan Municipal Health Committee mengeluarkan pernyataan "urgent notice on the treatment of pneumonia of unknown cause" (Hanoatubun, 2020). Virus Corona ini menyebar dengan sangat cepat bahkan sampai ke seluruh belahan dunia. Sampai saat ini negara yang mengkorfirmasi terkena virus Corona mencapai 188 negara. Penyebaran virus Corona yang telah meluas ke berbagai belahan dunia membawa dampak selain pada sektor kesehatan, melainkan juga pada sektor perekonomian Indonsia, baik dari sisi perdagangan, investasi dan pariwisata (Hanoatubun, 2020).

Penyebaran dan peningkatan jumlah kasus covid-19 terjadi secara tiba-tiba dan dengan waktu yang sangat cepat dan telah menyebar di seluruh belahan dunia termasuk Indonesia. Sampai dengan tanggal 15 Maret 2021, dilaporkan dalam berita harian KOMPAS.com telah tercatat total kasus terkonfirmasi sebanyak 120.399.298 total kasus terkonfirmasi, dari jumlah tersebut, sebanyak 2.664.622 dinyatakan meninggal dunia dan 96.944.566 orang dinyatakan pulih (Kompas.com, diunduh pada tanggal 15 Maret pukul 12.50). Sedangkan di indonesia, pada bulan Maret 2021, kasus COVID 19 terkonfirmasi sebesar 1.419.455, dari data tersebut 1.243 .117 orang dinyatakan sembuh dan 38.426 dinyatakan meninggal dunia (Kemenkes RI, 2021).

Salah satu sektor yang terdampak dari adanya pandemi Covid 19 ini adalah sektor perekonomian (Hanoatubun, 2020). Selain dalam Indonesia mengalami penurunan di sektor perekonomian secara global, pandemi Covid 19 telah berdampak kepada perubahan peta ekonomi rumah tangga, baik dalam hal pemasukan maupun pengeluaran. Sehingga, tidak jarang kehidupan rumah tangga kehilangan fungsi keseimbangannya (Alghifari et al,. 2020). Banyak keluarga yang mengalami shock (guncangan) ekonomi akibat pandemi yang mengakibatkan mereka sulit untuk memenuhi kebutuhan hidup dan banyak dari mereka menyelesaikan masalah ini dengan perceraian. Berbagai peristiwa yang terjadi secara tiba-tiba yang kemudian berdampak pada kondisi ekonomi dan kesejahteraan rumah tangga, seperti kebijakan Lockdown dan Social Distancing yang dikeluarkan pemerintah menimbulkan dampak positif dan negatif (Alghifari et al,. 2020). Dampak positifnya, kebijakan tersebut dapat memutus rantai penyebaran virus dan meminimalisir terpaparnya virus tersebut, namun di sisi lain kebijakan tersebut membuat masyarakat menjadi terbatas bahkan sampai tidak bisa bekerja sama sekali, karena sepi kemudian banyak usaha yang tutup, baik sementara bahkan bisa jadi selama-lamanya (Alghifari et al,. 2020).

Dampak dari pandemi Covid-19 ini telah menurunkan peluang mereka dalam menghasilkan pendapatan sehari-harinya, bahkan sampai 1.943 .916 pekerja yang diPHK secara besar-besaran yang terdiri dari 114.340 perusahaan (Yamali \& Putri, 2020). Kejadiaan ini akan mengalami peningkatan yang terus meningkat apabila pandemi ini berlangsung lama. Selain itu, dengan adanya kebijakan dari pemerintah kepada masyarakat untuk "stay at home" akan berdampak pada turunnya penghasilan masyarakat dari rutinitasnya secara signifikan, aktivitas ekonomi menjadi sangat terbatas, serta pengaruh lain yang mengikutinya (Mas'udi dan Winanti, 2020). Akibat beberapa faktor ekonomi yang ditimbulkan dari pandemi tadi, rumah tangga yang awalnya baik-baik saja kini mengalami guncangan karena salah satu pilarnya sedang terganggu dan tidak sedikit yang kemudian berlanjut kepada terjadinya perceraian. Ilustrasi di atas mendeskripsikan bahwa pandemi Covid 19 yang terjadi secara cepat dan tiba-tiba berdampak pada berbagai sektor kehidupan, salah satunya dalam sektor 
Jurnal Pengabdian dan

Penelitian Kepada Masyarakat (JPPM) e ISSN: 2775 - 1929

p ISSN: $2775-1910$
Vol. 2 No. 1 ekonomi. Tujuan penulis membuat tulisan ini untuk mencoba menelaah dan mencari tahu bagaimana dampak ekonomi di suatu keluarga pada masa pandemi yang dapat menyebabkan suatu rumah tangga mengalami perceraian. Tulisan ini juga akan mengaitkan antara fenomena di atas dengan menggunakan Teori Konflik. Selain itu, penulis berharap mendapatkan solusi yang tepat dalam mencegah terjadinya perceraian.

\section{METODE}

Penelitian ini bersifat eksplanatif karena di dalam penelitian ini menjelaskankan hubungan sebab akibat antara pengaruh adanya pandemi Covid 19 dengan meningkatnya angka perceraian. Menurut Umar (1999:36), penelitian eksplanatori (explanatory research) merupakan sebuah penelitian yang dilakukan untuk menganalisis suatu hubungan-hubungan antara satu variabel dengan variabel lainnya atau bagaimana suatu variabel mempengaruhi variabel lainnya. Penulisan artikel ini menggunakan pendekatan studi literatur. Teknik ini dilakukan dengan tujuan sumber yang dicari relevan dengan permasalahan yang diteliti. Studi literatur yang dilakukan oleh penulis ialah mencari 2 buku mengenai Dinamika Keluarga dan 9 artikel dan jurnal yang berkaitan dengan judul penelitian ini. Dengan demikian sumber yang telah dikumpulkan tersebut mampu untuk memperkuat dan memecahkan permasalahan penelitian.

\section{HASIL DAN PEMBAHASAN}

Tidak hanya dari sektor publik saja yang merasakan dampak buruk dari adanya pandemi covid 19 ini, melainkan dari sektor domestik juga ikut merasakan imbasnya (Hidayati, 2021). Seperti diberitakan di beberapa media massa, tentang banyaknya kasus perceraian di tengah pandemi covid ini, Kompas TV melansir bahwa Pengadilan Agama Kelas 1a Kabupaten Garut mencatat kenaikan drastis kasus perceraian selama masa pandemi Virus Corona. Setidaknya saat ini sekitar 3 ribu warga melakukan gugatan perceraian yang mayoritas disebabkan oleh masalah ekonomi rumah tangga. Dalam proses berlajannya rumah tangga, dapat dipastikan tidak akan berjalan mulus saja, pasti terdapat kerikil masalah baik kecil maupun besar. Hal ini dikarenakan pada hakikatnya perkawinan merupakan mengawinkan dua perbedaan (Hidayati, 2021). Riak gelombang yang kecil akan memperindah jalinan perkawinan itu, namun jika riak gelombang besar yang datang maka perselisihan, percekcokan dan pertikaianlah yang akan muncul, hingga seringkali perceraian menjadi jalan akhirnya (Fauziah, 2020).

\section{Makna Perceraian}

Dalam Kamus Bahasa Indonesia kata "cerai" dimaknai dengan pisah atau putusnya hubungan sebagai suami-istri. Sehingga "perceraian" merupakan kata yang merujuk kepada keadaan dari makna kata "cerai" tersebut. Sehingga dapat dipahami bahwa dalam sebuah perceraian, yang putus itu hanyalah hubungan sebagai suami dan istri, oleh karena itu keduanya tidak dibolehkan lagi bergaul layaknya suami dan istri pada umumnya (Alghifari et al., 2020). Sedangkan menurut Spremo (2020), menjelaskan bahwa perceraian merupakan peristiwa kehidupan dengan tingkat stres yang tinggi bagi seluruh anggota keluarga. Bahkan penelitian Sbarra (2015) menyatakan, pengalaman perpisahan atau perceraian memberikan resiko terhadap kesehatan yang memburuk dan resiko pada tingkat kematian. Untuk itu, tidak ada seseorang yang mengharapkan perceraian dalam rumah tangga yang telah dibangun.

Dalam penelitian ini, penggugat dalam perceraian mayoritas dilakukan oleh istri. Mayoritas istri (69,7\%) mengungkapkan bahwa alasan utama yang melatar belakangi terjadinya perceraian yaitu faktor ekonomi. Suami tidak mampu untuk memenuhi seluruh kebutuhan dasar keluarga dikarenakan jumlah pendapatan yang kurang muncukupi. Selain dari sisi istri, sebanyak $(57,8 \%)$ alasan suami saat meminta untuk berpisah dikarenakan timbulnya perselisihan di antara kedua belah pihak yang berlarut-larut (Wijayanti, 2021). Sebagian besar istri yang menjadi penggugat perceraian merupakan ibu rumah tangga dan hanya mengurus anak-anaknya di rumah (Wijayanti, 2021). Kondisi ini menunjukkan 
bahwa istri berada pada posisi yang belum merdeka secara ekonomi dan masih bergantung kepada suami. Ketika memutuskan bercerai, maka istri harus berusaha sendiri untuk memenuhi kebutuhan hidupnya. Perceraian akan berdampak pada kehidupan istri, salah satunya dapat menimbulkan kecemasan. Faktor penyebab kecemasan pada perempuan yang bercerai dikarenakan ketidaksiapan seorang ibu rumah tangga untuk bekerja di sektor publik (Pragholapati, 2020).

\section{Perceraian dalam Sudut Pandang Teori Fungsional Struktural}

Menurut Herbert Spencer, teori fungsional struktural melihat masyarakat sebagai oerganisme biologis yang terdiri dari organ-organ yang saling ketergantungan, maksud ketergantunagn disini yaitu hasil atau konsekuensi agar organisme tersebut dapat bertahan hidup. Ketika terjadi sedikit perubahan di masyarakat akan mempengaruhi elemen yang lain (Tristanto, 2020). Geoogde (2007) menjelaskan asumsi dasar bahwa setiap struktur dalam sistem sosial memiliki pengaruh fungsional terhadap sistem yang lain. Begitu pula dalam keluarga yang terdiri dari anggota-anggota keluarga yang saling berhubungan satu sama lain dan fungsional terhadap anggota keluarga lainnya. Dimana masing-masing anggota keluarga saling mempengaruhi, saling membutuhkan, serta saling mengembangkan hubungan intensif antar keluarga (Darmawati, 2017). Jika teori ini dikaitkan dengan meningkatnya angka perceraian di masa pandemi COVID-19, dapat berarti seorang suami merupakan bagian dari struktur sistem dalam keluarga. Karena produktivitas ekonomi baik lokal maupun global saat pandemi menurun, maka para pekerja yang umumnya merupakan seorang suami harus dirumahkan. Hal tersebut mengakibatkan suami tidak dapat menjalankan peranan dan tanggung jawabnya sebagai pencari nafkah utama dalam keluarga, sehingga mengganggu sistem yang ada dalam keluarga. Apabila permasalahan ini tidak segera diselesaikan, maka dapat terjadi konflik yang terus menerus yang tidak menutup kemungkinan berujung pada perceraian.

\section{Faktor Penyebab Timbulnya Perceraian}

Berbagai persoalan yang menerpa dalam kehidupan rumah tangga merupakan suatu hal yang biasa, tergantung bagaimana pasangan suami istri dapat mengatasi suatu masalah dengan baiktanpa harus melalui jalan perceraian. Bagi keluarga yang mampu menyelesaikan masalah dalam keluarga akan semakin memperkuat ketahanan keluarga begitupun sebaliknya. Berikut merupakan faktor-faktor terjadinya perceraian.

1. Menurut Karim (2004), pada usia muda seseorang masih dalam proses pembentukan kepribadian, kondisi ekonomi yang belum stabil dan kondisi keuangan yang belum mapan, sedangkan dalam perkawinan harus saling berbagi dengan pasangan. Ketidak mampuan berbagi dan memahami pasangan bisa mengarah pada perceraian.

2. Pendidikan mempengaruhi seseorang dalam mengambil keputusan ketika menghadapi permasalahan. Pendidikan berhubungan dengan pola pikir, persepsi, dan perilaku masyarakat secara signifikan dalam arti semakin tinggi tingkat pendidikan seseorang, maka semakin rasional dalam mengambil berbagai keputusan (Lontaan \& Kusmiyati, 2014).

3. Ekonomi menjadi alasan utama istri untuk bercerai dengan suaminya. Hasil ini menguatkan temuan BPS (2019), bahwa ekonomi merupakan faktor terbanyak kedua yang membuat istri memilih berpisah (120.732 kasus) setelah perselisihan dan pertengkaran yang terus menerus. Apalagi faktor eksternal dengan adanya pandemi Covid 19 membuat banyak pekerja yang di PHK secara mendadak, sehingga keuangan menjadi tidak stabil. Faktor ekonomi dapat memengaruhi hubungan sosial (Johnson, 1994).

4. Faktor perselisihan menunjukkan perbedaan pendapat yang memicu konflik rumah tangga. Konflik yang timbul dalam perkawinan bukan karena perbedaan antara suami istri, tetapi karena suami istri tidak mampu hidup ditengah-tengah perbedaan yang ada di antara mereka, dan perceraian dapat dipahami sebagai kegagalan suami istri dalam menegosiasikan bagaimana penyelesaian 
Jurnal Pengabdian dan

Penelitian Kepada Masyarakat (JPPM) e ISSN: 2775 - 1929

p ISSN: 2775 - 1910
Vol. 2 No. 1 konflik yang terjadi (Suhendi \& Wahyu, 2001).

5. Alasan lain yang memicu terjadinya perceraian yaitu perselingkuhan yang dilakukan oleh istri dan suami. Hal ini akan bermuara pada ketidak harmonisan hubungan di antara keduanya (Ghoffar, 2006). erselingkuhan umumnya terjadi kepada pasangan yang kurang memiliki kualitas keagamaan, lemahnya dasar cinta, sikap egois kepada pasangan, komunikasi yang kurang baik, emosi kurang stabil, dan kurang mampu menyesuaikan dirinya (Surya, 2009).

\section{Dampak Pandemi Covid 19 Terhadap Fenomena Perceraian}

Selama pandemi Covid 19, terjadi peningkatan jumlah kasus perceraian (Wijayanti, 2021). Berdasarkan data dari Mahkamah Agung, suami istri yang melakukan pendaftaran perceraian yang awalnya berjumlah 20 ribu kasus pada periode April dan Mei 2020 mengalami peningkatan menjadi 57 ribu pada periode Juni dan Juli 2020. Dilansir dari Suara.com, pada bulan Juni dan Juli 2020, jumlah kasus gugatan cerai melonjak hingga $80 \%$ yang diajukan ke Pengadilan Agama mayoritas diajukan oleh pihak istri. Jika ditinjau lebih jauh, peningkatan kasus perceraian paling tinggi terjadi di provinsi Jawa Tengah. Provinsi Jawa Tengah sebagai wilayah paling banyak mengalami peningkatan kasus perceraian (Detik News, 2020). Berdasarkan data Pengadilan Agama Kabupaten Banyumas, mencatat pada bulan Juni 2020 sebagai bulan menuju new normal terdapat peningkatan sebesar 48 kasus, dibandingkan keadaan normal bulan Januari 2020 bila jumlah tersebut disandingkan saat pandemi pada bulan MaretMei ada peningkatan sebanyak 464 kasus. Hal ini bermakna bahwa dalam satu hari terdapat sekitar 24 pasangan yang mendaftarkan perceraiannya.

Selama pandemi Covid 19 penyumbang faktor terbesar pasangan suami istri melakukan perceraian yaitu karena perselisihan atau pertengkaran dan masalah ekonomi (Tristanto, 2020). Kebijakan yang dikeluarkan oleh pemerintah untuk memutus rantai penyebaran virus dengan menetapkan kebijakan Pembatasan Sosial Berskala Besar (PSBB), social distancing, dll. Kebijakan ini menuntut keluarga untuk melakukan berbagai aktivitas dari rumah, seperti kegiatan belajar, beribadah, hingga bekerja. Keadaan ini membuat masing-masing anggota keluarga menghabiskan lebih banyak waktunya di rumah. Ada yang menyikapinya dengan positif, namun ada juga yang menyikapinya secara negatif hingga berujung pada konflik (Wijayanti, 2020). Keadaaan ekonomi yang semakin sulit di masa pandemi, menjadi salah satu alasan kuat terjadinya konflik yang terjadi di dalam hubungan suami istri. Banyak suami yang di PHK pada masa pandemi yang berakibat pada ketidakstabilan finansial dalam rumah tangga, sehingga suami tidak lagi memberikan nafkah kepada istri dan tidak mampu memenuhi kebutuhan hidupnya, yang akhirnya menimbulkan permasalahan di dalam rumah tangga yang tidak menutup kemungkinan terjadinya perceraian (Bakhtiar, 2020). Fauziah et al. (2020) dalam analisisnya menjelaskan bahwa selama pandemi COVID19, angka perceraian di Indonesia meningkat akibat kesulitan ekonomi yaitu sebesar 5 persen. Akibat pandemi covid 19, perubahan ekonomi yang terjadi tidak mampu diterima oleh semua keluarga (Wijayanti, 2020). Ada keluarga yang tidak memiliki cukup tabungan untuk menghadapi kondisi darurat dan secara tiba-tiba seperti pandemi ini. Akhirnya kerap terjadi konflik, masing-masing memiliki keinginan serta gagasan yang ingin dihargai dan dilaksanakan, sementara pihak lainnya memiliki harapan yang berbeda (Wijayanti, 2020). Diantara pasangan suami dan istri, ego dan pengakuan tinggi kadang sulit untuk dibendung.

\section{Upaya Mencegah Perceraian di Tengah Pandemi}

Tidak ada satupun pasangan yang ingin mengalami keretakan dalam kehidupan rumah tangganya yang berakhir dengan jalan perceraian (Tristanto, 2020). Sebab dampak yang ditimbulkan dari perceraian tidak hanya dialami oleh pelaku perceraian saja, yaitu suami dan istri, namun juga pada keluarga besar kedua belah pihak dan yang lebih parah lagi adalah anak-anak bisa mendapatkan dampak yang besar dari sebuah perceraian 
Jurnal Pengabdian dan

Penelitian Kepada Masyarakat (JPPM) e ISSN: 2775 - 1929

p ISSN: $2775-1910$
Vol. 2 No. 1
(Hasanah, 2020). Menurut DeVito (2007) dalam Equtiy Theory, keseimbangan sebuah hubungan sangat dibutuhkan dalam mempertahankan hubungan. Keseimbangan yang dimaksud tidak hanya berupa materi, namun dapat berupa perhatian, pengorbanan, dan pembagian tugas dalam hubungan. Jika keseimbangan tidak terwujud, maka keutuhan hubungan dapat terancam. Berbagai upaya preventif telah dilakukan pemerintah dalam menyikapi peningkatan kasus perceraian sebagai berikut:

1. Pembatasan usia perkawinan, batasan bagi laki-laki dan perempuan di atas 19 tahun. Lebih lanjut, Badan Kependudukan dan Keluarga Berencana Nasional (BKKBN, 2013) sebagai lembaga pemerintah yang fokus pada persoalan kependudukan baik secara kuantitas maupun kualitas memiliki batasan dalam hal pernikahan yakni 21 tahun bagi perempuan sedangkan 25 tahun bagi laki-laki. Pertimbangan 21 tahun bagi perempuan karena perempuan di atas usia 20 tahun dinilai sudah matang dalam segi reproduksi sehingga cocok untuk menikah. Selain itu, pada usia tersebut para pasangan diharapkan sudah memiliki pendapatan yang cukup sehingga sudah mapan dari sisi ekonomi.

2. Dalam hal pernikahan, melalui BKR (Bina Keluarga Remaja) para orang tua mampu membina remajanya untuk tidak menikah muda dan mempersiapkan semuanya sebelum menikah, sehingga menjadi tindakan preventif untuk menghindari perceraian. Upaya preventif lainnya yang dilakukan pemerintah ialah dengan adanya konseling pranikah bagi para calon pengantin, sehingga bisa mengonsultasikan diri baik dari sisi kesehatan, finansial, dan lain-lain sehingga mereka dapat saling memahami calon pasangan masingmasing.

3. Pusat Informasi dan Konseling Remaja/Mahasiswa (PIK R/M) menurut BKKBN (2013) merupakan sebuah wadah kegiatan program KKB (Kependudukan dan Keluarga
Berencana) dan PK (Pembangunan Keluarga) yang dikelola dari, oleh, dan untuk remaja guna memberikan pelayanan informasi dan konseling tentang kependudukan, keluarga berencana dan pembangunan keluarga.

\section{SIMPULAN}

Umumnya, semua keluarga pasti pernah mengalami suatu permasalahan. Apabila suatu masalah tidak diselesaikan dengan cepat maka akan menjadi sebuah konflik rumah tangga yang berlarut-larut dan mungkin akan bermuara pada perceraian. Pada masa pandemi COVID-19, faktor penyebab perceraian cenderung disebabkan oleh permasalahan ekonomi, ketidakseimbangan aktivitas dan waktu bersama, berubah pola komunikasi, serta faktor usia dalam membina rumah tangga. Perceraian karena konflik dalam rumah tangga yang disebabkan oleh masalah ekonomi pada saat pandemi COVID19 merupakan sesuatu yang saling berhubungan. Hal tersebut karena banyak suami terkena pemutusan hungan kerja (PHK), sehingga berdampak pada sektor perekonomian keluarga. Kondisi ini akan memicu stress dan emosi pada pihak suami karena memikirkan biaya hidup sehari-hari.

Selain itu, pandemi COVID-19 merupakan badai bagi seluruh pasangan suami istri khususnya bagi pasangan yang menikah di bawah umur. Hal tersebut dikarenakan pasangan yang menikah di bawah umur belum siap mengatasi lika-liku pertikaian yang mereka jumpai seperti pada saat pandemi COVID-19. Ketidaksiapan pasangan tentu berhubungan dengan tingkat kedewasaan, dan cara berpikir, serta bertindak dalam mengambil keputusan di rumah tangga. Dari hasil penelitian di atas, menunjukkan adanya hubungan antara dampak dari pandemi Covid19 terutama dari sektor ekonomi terhadap meningkatnya fenomena perceraian yang terjadi di Indonesia. Hal yang perlu diperhatikan menurut penulis, suami istri harus berada dalam satu frekuensi yang sama dalam menyelesaikan setiap persoalan rumah tangga. Dikarenakan sebagai lembaga sosialisasi pertama, masing-masing struktur dalam lembaga keluarga hendaknya memiliki 
Jurnal Pengabdian dan

Penelitian Kepada Masyarakat (JPPM) e ISSN: 2775 - 1929

p ISSN: $2775-1910$ interaksi dan komunikasi yang baik antara anggota keluarga sehingga ada kesempatan dan tercipta keharmonisan dalam keluarga.

\section{DAFTAR PUSTAKA}

Alghifari, A., Sofiana, A., dkk. 2020. Faktor Ekonomi dan Dampaknya Terhadap Kasus Perceraian Era Pandemi COVID-19 dalam Tinjauan Tafsir Hukum Keluarga Islam (UIN Raden Intan, Lampung). Civil and Islamic Family Law 1(2):1689-1699

Bakhtiar, Y. 2020. Penelantaran Rumah Tangga Sebagai Bentuk Kekerasan dalam Rumah Tangga yang Menjadi Alasan Perceraian di Masa Pandemi COVID-19 (Universitas Negeri Padang, Sumatera Barat). Legitimasi 9(2):281-294

Fauziah, A., Fauzi, A., dkk. 2020. Analisis Maraknya Perceraian Pada Masa Pandemi COVID-19 (IAIN, Surakarta). Islamic Law 4(2):181-192

Hanoatubun, S. 2020. Dampak COVID-19 Terhadap Perekonomian Indonesia (Universitas Kristen Satya Wacana). Education, Psychology, and Counseling 2(1):146-153

Hidayati, L. 2021. Fenomena Tingginya Angka Perceraian di Indonesia Antara Pandemi dan Solusi. Khuluqiyya 3(1):71-87

Radhitya, T. 2020. Dampak Pandemi COVID19 Terhadap Kekerasan dalam Rumah Tangga (Universitas Padjajaran, Jawa Barat). Kolaborasi Rsolusi Konflik 2(2):111-119

Subhardini, M. 2020. Dinamika Keluarga Pada Masa Pandemi COVID-19. Dalam Fahrudin, A., Mas'ud, F., Rose, N. \& Wardani, L. (ed.). "Perceraian di Masa Pandemi COVID-19: Masalah dan Solusi”. Selected Reading, hlm. 79-90. Jakarta: UMJ Press.

Thaha, A. 2020. Dampak COVID-19 Terhadap UMKM di Indonesia (Universitas Hasanuddin). Brand 2(1):147-153

Tristanto, A. 2020. Perceraian di Masa Pandemi COVID-19 dalam Perspektif Ilmu Sosial (Universitas Andalas,
Sumatera Barat). Sosio Informa 6(3):292-304

Wardani, L. \& Christanto, A. 2020. Dinamika Keluarga Pada Masa Pandemi COVID-19. Dalam Fahrudin, A., Mas'ud, F., Rose, N. \& Wardani, L. (ed.). "Dampak COVID-19 Terhadap Rumah Tangga". Selected Reading, hlm. 135-139. Jakarta: UMJ Press.

Wijayanti, U. 2020. Analisis Faktor Penyebab Perceraian Pada Masa Pandemi COVID-19 di Kabupaten Banyumas (Semarang, Jawa Tengah). Ilmu Keluarga dan Konsumen 14(1):14-26

Yamali, F. \& Putri, R. 2020. Dampak COVID19 Terhadap Ekonomi Indonesia (Universitas Batanghari, Jambi). Economics and Business 4(2):384-388 